\title{
AWARENESS AND USE OF WHATSAPP FOR BANKING AND FINANCIAL SERVICES: A STUDY OF SOCIAL MEDIA USERS IN NORTH-CENTRAL NIGERIA
}

\author{
Silas Udenze \\ University of Abuja, Nigeria \\ $+2348154846838,+2348069391346$ \\ udenzes@gmail.com \\ Edmund Chukwuma Onwuliri \\ University of Abuja, Nigeria \\ $+2348036545508$ \\ eddyonwuliri@gmail.com \\ BibianUgoala \\ National Open University of Nigeria, Abuja \\ $+2348034082115$ \\ bugoala@ noun.edu.ng
}

\begin{abstract}
Social media have become a fundamental ingredient in both the social and economic life of contemporary society. Social networking platforms have become an interesting vehicle for the banking sector to manage contact and interaction with their existing and potential customers. This study investigates users' awareness and the use of WhatsApp for banking activities in North-Central Nigeria. Based on a quantitative research approach, the study surveyed 400 respondents who have adopted WhatsApp Banking. The study's significant findings revealed a low level of awareness of this banking method among social media users. Besides, the percentage of users that utilised the platform for banking-related activities corroborated the deficient awareness as discovered in the study. Nevertheless, the audience is sceptical that the country's poor internet infrastructure might not permit the innovation to thrive. Hence, the study recommends that the banks concerned should endeavour to create more awareness about WhatsApp Banking, and there is a need for an urgent improvement in the internet facilities in the country in order to engender seamless technological advancement
\end{abstract}

Keywords: Social media, WhatsApp, WhatsApp Banking, Perception, Nigeria, Awareness

\section{INTRODUCTION}

Information and Communication Technologies (ICTs) play critical roles in diverse facets of our daily lives. Today, human life has experienced dramatic changes due to advances in technology. This advancement has made work-life to be easier, faster, and more convenient. With the advent of technology, the world has become more addicted to the usage of such latest advancements. With the expanding internet infrastructures, human beings are getting more chances to be aware of their environment. Advances in internet availability has neutralised the hitherto geographical distance that constitutes a considerable barrier in communication. It is not alarming to know that over 2 billion people use the internet on a daily basis, and they increasingly utilise the World Wide Web daily in the form of chats, messengers, and emails to communicate with others (Khan, Al-balushi, Algaithi, and Alshihi, 2017). Society is continually evolving easier methods for interaction; hence social media emerged as an easy linking tool in the internet infrastructure. According to Mutunga (2014), social media is an aggregation of online channels dedicated to community-based 
input and interaction. Bullas (2014) shows that almost $72 \%$ of internet users are now active in social media.

In the last years, we have witnessed a significant growth of online user-generated content (UGC) through the use of a series of tools that have generically been defined as social media. Miranda, Chamorro, Rubio and Morgado (2013) reiterate that social media technologies take on a plethora of forms including collaborative projects (e.g., Wikipedia), blogs and microblogs (e.g., Twitter), content communities (e.g., YouTube), social networking sites (e.g., Facebook), virtual game worlds (e.g., World of Warcraft), and virtual social worlds (e.g. Second Life). Boyd \& Ellison (cited in Udenze, 2018) describe a social network as webbased service that permit individuals to constitute a public or semi-public profile within bounded systems, articulates a list of other users with whom they share connections and view and traverse their list connection and those made by others within the system.

Social networking sites (SNS) have become well-known in today's e-community as they provide a platform for people across the globe to communicate, exchange ideas, share knowledge, interests and send messages to each other regardless of geographic distance (Sawyer 2011, cited in Udenze, 2019b). The first social networking site known as Six degrees was launched in 1995. After then, others came on board- Livejournal, AsianAvenue, BlackPoint, LunarStorm, MiGente, Cyworld, Ryze, Fotolog, Friendster, amongst others (Udenze, 2019). Today, numerous social network sites satisfy the yearning of varying sectors of society.

The focus of the current study is on WhatsApp. WhatsApp is a computer-mediatedcommunication platform that allows users to send contents like pictures, audio, videos, make voice and video calls, send documents etc. It is a freeware, and cross-platform that is inbuilt with an end-to-end encrypted instant messaging feature for smartphones (Udenze, 2017a). These unique features of the mobile application distinguish it from other social networking sites. A few studies have been conducted on the use of social media in the banking and related industries (Costin, 2015; Ruppert, 2013; Zembik, 2014; Kirakosyan, 2014a; Dawar, Rabb, 2015; Adalarasu and Padmaavathy, 2016; Khan et al. 2017). However, at the moment, the current study argues that there is a dearth of research on, mainly, audience awareness and use of WhatsApp for banking activities in Nigeria, North-Central region, to be precise. It is also germane to state that, globally, WhatsApp is an emerging research domain, and it is grossly under-investigated in Nigeria. Hence, this study fills the apparent vacuum in these areas.

\section{STATEMENT OF PROBLEM}

Since the emergence of WhatsApp in 2009, the app has continually metamorphosed from just a messaging platform to encompass a plethora of functions. Today, with WhatsApp, users can read and download documents on WhatsApp; we can send location maps; we can make video calls; we can record voice notes, and very recently, the app enables us to conduct bank transactions. A growing number of organisations and associations are embracing the use of WhatsApp in order to ease communication barriers and to cut costs. They have discovered the seeming potential of WhatsApp in promoting customer relations and increasing product patronage. Currently, some Nigerian banks are offering access to financial services through WhatsApp. Since this kind of social media banking is new and is still evolving in Nigeria, it is unknown to which extent people are aware of it and utilise it to carry out banking services, particularly in North-Central Nigeria. According to a recent article by Kemp (2019), with 
$85 \%$ of Nigeria's 24 million active social media on WhatsApp, it has become the preferred platform for small and medium scale businesses in Nigeria (Techpoint.africa, 2018). Hence, the researchers were interested in finding out whether Nigerians are aware and also use the platform for banking activities.

\section{OBJECTIVES OF THE STUDY}

This study explores audience awareness and use of WhatsApp for banking activities in NorthCentral Nigeria. More specifically, the following objectives were investigated:

$>$ To ascertain the extent to which the audience are aware of WhatsApp banking.

$>$ To find out the extent to which the audience use WhatsApp banking.

$>$ To understand how the audience perceive WhatsApp banking.

$>$ To determine how the audience assess WhatsApp banking to other forms of internet banking.

\section{A CONCEPTUAL OVERVIEW OF WHATSAPP}

WhatsApp is a multimedia communication platform established in 2009 by two former employees of Yahoo. WhatsApp reached 1 billion monthly active users in 2016. The app lets users send content like pictures, audio, videos, documents, and voice calls (Udenze, 2019b). Another feature of WhatsApp is its group chat functionality. The group chat feature allows a user to communicate with up to 256 people at once (whatsapp.com, 2017). The group chat platform on WhatsApp affords diverse forms of online communities to emerge; individuals that share similar interests from different backgrounds like the academic, religious, entertainment, management, media, and professional bodies have come to see the importance of the WhatsApp group.

Besides, WhatsApp's broadcast lists enable the simultaneous dissemination of messages to a wider audience. The broadcast feature permits a user to create a broadcast list of 256 contacts and repeatedly send messages to the contacts without having to select the recipients individually anytime the need arises. The app is for android, iOS, and Windows phone platforms (WhatsApp.com). The WhatsApp app is connected to the user's mobile number, but it can also be accessed through any web browser on a personal computer once an account has been created through the app on the user's phone. The service has end-to-end encryption to protect users' privacy (blog.WhatsApp.com), making it suitable for health-related endeavours.

Moreover, Jisha K. and Jebakmar (2014) reiterate that the under-listed characteristics distinguish WhatsApp from other social media platforms:

$>$ Affordability: WhatsApp is downloadable and used for a year for free. It demands a subscription fee of 0.99 US dollar per year.

> Easy chatting: Chatting on WhatsApp is easy with friends and family. If an individual has the application installed on their phone, and they have your phone number, you are automatically added to their contact list if your number is registered to a WhatsApp account.

$>$ Backs up chat history: WhatsApp allows you to preserve your chat for a selected time.

$>$ Enables the user to monitor when someone is online, and the last time he or she logged in. 
$>$ Breaks geographic constraints: You can chat with users of WhatsApp wherever they are in the globe.

$>$ Speed: WhatsApp messages are fast in delivery as far as there is a reliable and robust internet connection.

$>$ Offer group chat facility: WhatsApp allows individuals to create a group and chat with members.

$>$ Easy to operate: WhatsApp does not require a login and logout procedures. The platform works whenever there is an internet connection.

\section{REVIEW OF RELATED LITERATURE: SOCIAL MEDIA AND THE BANKING SECTOR}

Imagine you are chatting with your colleague on WhatsApp. After sending him a copy of a business proposal both of you discussed earlier in the day, and you discuss the cost of mailing the document overseas, and he requests for your account number to send the money. Instead of using other electronic or internet means, he simply finds your bank as a contact on WhatsApp and proceeds to begin the process of transferring the money. He completes the transaction in less than four minutes without exiting the messaging app. The above description and other financial services are obtainable within WhatsApp Banking.

Techpoint.africa (2018) described WhatsApp Banking as an appendage of Chat Banking already available on Facebook. It further opined that since WhatsApp is the most used messaging platform in Africa, it gives banks a wider reach than Facebook Messenger. Absa Bank first launched WhatsApp banking in July 2018. Currently, some Nigerian banks are offering access to financial services through WhatsApp. These banks are: United Bank for Africa (UBA), First Bank of Nigeria (FBN), Guaranty Trust Bank (GTBank), Access Bank and Zenith Bank. In the case of Zenith Bank, it is known as Qwerty Banking. Customers can conduct banking activities on mobile messaging platforms by simply activating the Zenith Bank keyboard interface on the bank's app (Techpoint.africa, 2018).

Miranda, Barriuso and Cortés (2013) argue that the phenomenon of social media originated and started to flourish when the global financial meltdown was in full swing; it is only now that the financial sector has realised that this platform presents an opportunity that they cannot afford to ignore. As banks and financial institutions recover from the crisis and look towards rounded growth, social media is starting to be a part of their overall strategy (Dinesh, 2011). Studies (Hajli, 2014; Chen and Beaudoin, 2016; Bohlin, Shaikh and Hanafizadeh, 2018) have asserted that social media provides the platform to promote businesses, and fosters interaction that allows consumers and businesses to create and develop new and real ways of interacting and have a tremendous prospect for business, including for financial institutions. Also, social media are referred to as a less expensive and readily available avenue for interacting with a large number of people in a short time (Madziwa and Sibanda, 2018).

There are numerous merits for using social media for financial and related activities, some of the essential benefits being: instant feedback from customers over existing and potentials offering, enhanced brand visibility, and customer service, future customer generations, increased business potential from social referrals and cross-selling opportunities, and enhanced marketing tools for gaining customer retention and advocacy ( Miranda et al., 2013). Adalarasu and Padmaavathy (2016) discovered that banks carry out their business activities through social media to offer their customers a better experience and to be more 
responsive. Similarly, Yasa and Mucan (2005) proffered that banks need to use social media user-friendly interactive system so as to understand customers' special needs and create more loyal customers. Alotaibi (2013) asserted that there exists a strong effect on the social network dynamics of Twitter in the banking sector. Kirakosyan (2014a) found that social media is a potent tool for acquiring clients in the banking sector, and the management needs to identify avenues in which to make profitable use of social media. Further, Kirakosyan (2014b) claimed that for social media to succeed, the elements of conversation, communication, and interactions are essential, followed by marketing. Further, Njoroge and Koloseni (2015) affirmed that for social networks to positively impact the banking sector, the customer's trusts would be premised on security and privacy of their information through a developed trust.

Khan et al. (2017) corroborated Njoroge and Koloseni's affirmation as they predicated that the customers are not comfortable with using social media as they are scared that their information might be stolen or misused; hence, customers do not perceive social media as an attractive marketing tool. However, Dehghani, Nourani, and Abardeh (2012) claimed that new and small banks use social media to improve their competitiveness in the market and establish links with their clients to achieve customer satisfaction. Costin (2015) averred that social media banking is no longer a concept but is a matter of fact which needs more attention and adjustment as a catalyst to change the customer approach.

\section{Domestication Theory}

The current study is underpinned and guided by the domestication theory. The domestication (adoption and use) of new technology is a trending phenomenon in media studies. The theory has its root in a German Ethnologist, Herman Bausinger, but was later fine-tuned by Rogers Silverstone in the early 1990s. Domestication theory is a philosophy in media studies that illustrate the steps by which modernization, especially new technology, is 'tamed' or appropriated by its users (Ayotunde, 2012). This theory explains the process of understanding the sophistication of how ICTs are experienced in everyday life (Ahad and Lim, 2014). Domestication clarifies a methodology of how technology affects society, especially at the household level and how society affects technology. Roger Silverstone's domestication demonstrates how innovators design technologies to be user-friendly and how users communicate their demands to innovators (prezi.com, 2014).

Furthermore, domestication also considers how innovators seduce the public into becoming their consumers. These days, manufacturers of mobile devices and software are always in competition to satisfy consumers' needs. For instance, the smartphones metamorphosed from a bulky, unattractive, with less software to a stylish, portable, and attractive device that accomplishes more within seconds. This indicates the roles of individuals who have taken advantage of this innovation by creating new media platforms (Ayotunde, 2012).

Deirdre (2007) elaborated on the four phases of domestication: Appropriation is the first phase of domestication. In this phase, possession and ownership are central. The acquisition of technology is the pre-eminent activity. A technology gets apportioned as it is sold and then owned or possessed by an individual. Objectification describes how values, tastes, or styles are communicated via the display of the new technology. It involves both a spatial/structural aspect (where it is placed in the house) and a physical aspect (how it is fitted in the time structure). (Silverstone et al. as cited in Hynes and Richardson, 2009). The incorporation phase emphasizes how the new technology is used, and the physical feature is more central in 
this stage. Silverstone et al. (1992) suggest that for a technology to be integrated, it has to be gravely used, such as in the performance of a task. Conversion is the final phase of domestication. This phase is concerned with how users speak and articulate their relationship with technology. This involves the bigger audience, discussion about the technology, and how the users use it in a way that the designer of the technology may not be visualized.

Considering the evolution of WhatsApp, arguably, the platform has undergone these phases of domestication, and we can argue that the app is in its conversion stage at the moment. WhatsApp is put to varying uses directly or indirectly in almost every sphere of human endeavour today so long as it concerns communication. For instance, in schools, churches, mosques, corporate organizations, families, informal associations etc. we have experienced the domestication of WhatsApp for different purposes. This theory is germane to this study because it establishes a relationship between the innovation- WhatsApp and how these banks and their customer may have tried to appropriate, objectify, incorporate and even convert the technology into banking services.

\section{METHODOLOGY}

The current study employed a quantitative design, precisely, survey. For convenience, the study area was the North-Central geopolitical zone, one of the six geopolitical zones in Nigeria, comprising five states, including Abuja, Nassarawa, Plateau, Benue, Niger, Kogi, and Kwara state.According to the National Bureau of Statistics (NBS) (2007), the study population of the North-Central zone is 20, 266,257, according to official census results. For the purpose of this study, and for convenience, only three states were covered- FCT, Niger, and Nassarawa state. A sample size of 400 was arrived at using Taro Yamane (1967) formula for determining sample size. The sample selection for the survey was made via a multi-stage approach covering state level, senatorial zone level, local government level, and town level.

A structured questionnaire was employed for data collection. The study is limited to four banks that have introduced WhatsApp banking at the time of the study: Access Bank, First Bank, Guarantee Trust Bank (GTB), and United Bank for Africa (UBA). For easy accessibility to the research population, the questionnaire was administered at the premises of these banks through the help of eight research assistants. For ethical purposes and for a study that involves human subjects, the respondents' consents were sought and obtained, and they were assured that their personal information would remain anonymous.

\section{DATA ANALYSIS AND PRESENTATION}

Out of the 400 questionnaire copies administered in August 2018, 386 copies representing $96.5 \%$ were retrieved and 18 copies representing $3.5 \%$ were not. Hence, the response rate stood at $96.5 \%$. The high return rate of questionnaires was possible because the authors paid attention to the importance of engaging the sampled population on the purposes of the study. Besides, the respondents were assured of their privacy, and the research assistants patiently waited for them to read and answer the questionnaires before handing them in. However, this approach was rigorous and time-consuming as it took the researchers and the research assistants longer days to distribute and collect the research instrument.

The respondents' demographic features revealed that $52.07 \%$ of them were female, while $47.92 \%$ were male. Also, 27.46\% of the respondents were between the ages 15 and 30, $61.65 \%$ were between 31 and 45, 10.88\% were between 46 and above. Furthermore, 15.02\% of the respondents had First School Leaving Certificate (FSLC) as their highest educational 
qualification; $23.57 \%$ had Senior School Certificate (SSCE), $18.65 \%$ had Diploma; $33.67 \%$ had Bachelor's degrees or Higher National Diploma (HND), and 9.06\% had postgraduate qualifications.

Table 1: Awareness and Usage of WhatsApp Banking

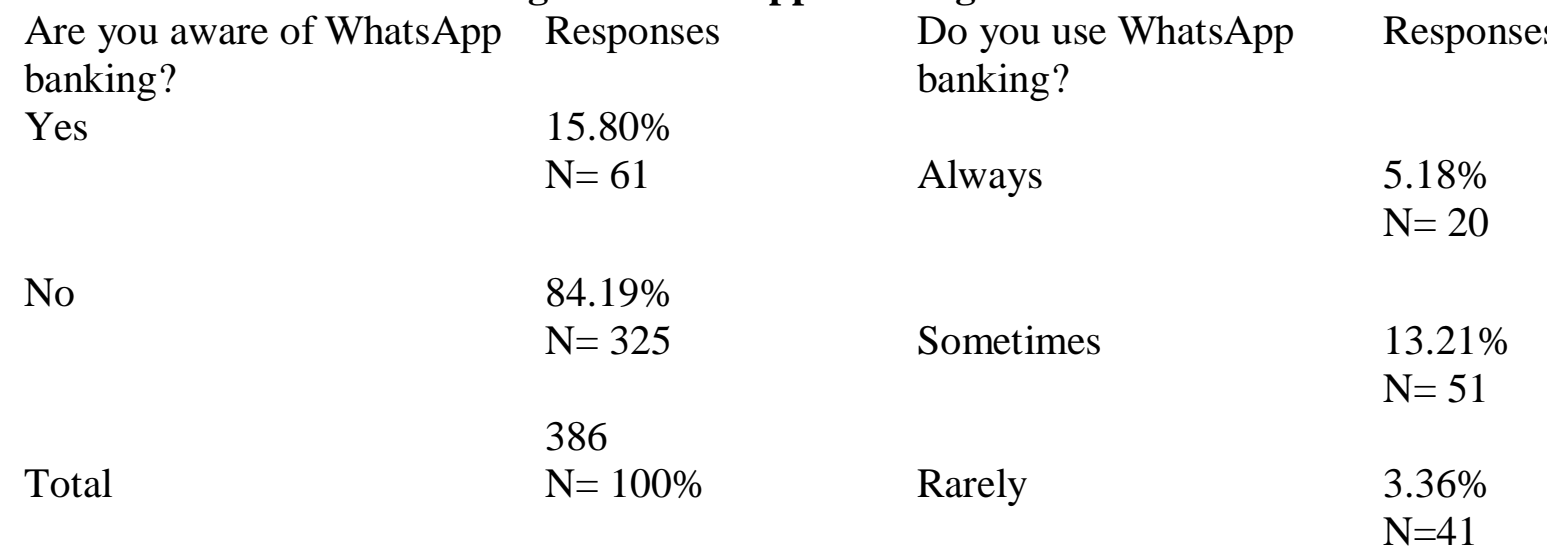

$\begin{array}{cl}\text { Never } & 78.23 \% \\ & \mathrm{~N}=302 \\ \text { Total } & 100 \% \\ & \mathrm{~N}=386\end{array}$

The data above revealed that a majority of the respondents, $84.19 \%$ in the study, are not aware of WhatsApp banking, while $15.80 \%$ of the population averred that they are aware of WhatsApp banking. This indicates that WhatsApp banking is not popular at the moment. Also, following the abysmal awareness of WhatsApp banking, its usage corroborated low awareness. About $78.23 \%$ stated that they have never used WhatsApp for banking; 3.36\% said they rarely use it; $13.21 \%$ confirmed that they use it sometimes while $5.18 \%$ ticked that they always use it.

Table 2: Perception of WhatsApp Banking

Do you think the Responses introduction ofWhatsApp banking will further ease banking?

Yes

\section{$85.23 \%$}

$\mathrm{N}=329$

$14.76 \%$

No

Total
Do you think the current Internet technology can sustain WhatsApp banking?
386

No
Responses

Do you estimate that more people would adopt WhatsApp banking if they are aware?

$\begin{array}{ll}52.07 \% & \text { Yes } \\ \mathrm{N}=201\end{array}$

$$
\mathrm{N}=201
$$

$47.92 \%$

$\mathrm{N}=51$

No

$\mathrm{N}=386 \quad$ Total

$\mathrm{N}=100 \%$

Responses C 
The above table highlights the respondents' responses to their perception of WhatsApp. First, the population strongly feels that the introduction of WhatsApp banking will ease banking activities- $85.23 \%$ reiterates this perception while $14.76 \%$ responded in the contrary. On whether the country's current state of internet infrastructure could sustain WhatsApp banking, $52.07 \%$ believe that the current state of internet infrastructure can sustain WhatsApp banking while $47.92 \%$ think that the country's internet infrastructure cannot sustain WhatsApp banking. Further, $90.41 \%$ believe that more people will adopt WhatsApp banking if they are aware of its existence, and $9.58 \%$ believe otherwise.

The above table highlights the respondents' responses to their perception of WhatsApp. First, the population strongly feels that the introduction of WhatsApp banking will ease banking activities- $85.23 \%$ reiterates this perception while $14.76 \%$ responded on the contrary. On whether the country's current state of internet infrastructure could sustain WhatsApp banking, $52.07 \%$ believe that the current state of internet infrastructure can sustain WhatsApp banking while $47.92 \%$ think that the country's internet infrastructure cannot sustain WhatsApp banking. Further, $90.41 \%$ believe that more people will adopt WhatsApp banking if they are aware of its existence, and $9.58 \%$ believe otherwise.

Table 3: Assessment of WhatsApp Banking

\begin{tabular}{|c|c|c|c|c|c|c|c|}
\hline $\begin{array}{l}\text { Do you } \\
\text { thinkWhats } \\
\text { App } \\
\text { banking } \\
\text { might } \\
\text { supersede } \\
\text { other forms } \\
\text { of internet } \\
\text { banking? }\end{array}$ & Responses & $\begin{array}{l}\text { Do you } \\
\text { think using } \\
\text { WhatsApp } \\
\text { banking } \\
\text { would have } \\
\text { any } \\
\text { particular } \\
\text { advantage? }\end{array}$ & Responses & $\begin{array}{l}\text { Do you } \\
\text { think } \\
\text { WhatsApp } \\
\text { banking } \\
\text { would } \\
\text { compleme } \\
\text { nt other } \\
\text { forms of } \\
\text { internet } \\
\text { banking? }\end{array}$ & Responses & $\begin{array}{l}\text { Do you } \\
\text { think } \\
\text { WhatsApp } \\
\text { banking } \\
\text { would } \\
\text { create } \\
\text { personal } \\
\text { link } \\
\text { between } \\
\text { the } \\
\text { customer } \\
\text { and the } \\
\text { bank? }\end{array}$ & $\begin{array}{l}\text { Response } \\
\mathrm{S}\end{array}$ \\
\hline
\end{tabular}

Yes

$50.25 \%$
$N=194 \quad$ Yes

$\begin{array}{ll}64.50 \% & \text { Yes } \\ \mathrm{N}=249\end{array}$

$94.81 \% \quad$ Yes

$69.17 \%$

$\mathrm{N}=249$

$\mathrm{N}=366$

$\mathrm{N}=267$

No $\quad 49.74 \%$

$\mathrm{N}=192$

No

$35.49 \%$

No

$5.18 \%$

$\mathrm{N}=137$

$\mathrm{N}=20$

$30.82 \%$

$\mathrm{N}=119$

386

Total

$\mathrm{N}=100 \% \quad$ Total

$\begin{array}{ll}386 \% & \text { Total } \\ \mathrm{N}=100 \%\end{array}$

386

Total

386

$\mathrm{N}=100 \%$

Firstly, from the table above, 50.25\% affirmed that WhatsApp banking is likely to supersede other forms of internet banking. Nearly $49.74 \%$ of the respondents maintained that WhatsApp banking is not likely to surpass other forms of internet banking. Secondly, $64.50 \%$ of the population asserted that WhatsApp banking would be of advantage to the banking sector, 
while $35.48 \%$ opined that the introduction of WhatsApp banking would not be of any advantage. Lastly, $94.81 \%$ confirmed that WhatsApp banking would be complementary to other forms of internet banking; however, $5.18 \%$ do not believe that WhatsApp banking will complement other forms of internet banking.

\section{DISCUSSION OF FINDINGS}

The study explores users' awareness and the use of WhatsApp for banking activities in NorthCentral Nigeria (FCT, Niger, and Nasarawa states). The current study revealed that a considerable number of respondents within the North-Central are not aware of WhatsApp Banking. The findings show that $15.80 \%, 61$ respondents argued that they are aware of the banking method. Nonetheless, 325 respondents representing $84.19 \%$ averred that they are not aware of WhatsApp Banking. These statistics explain that WhatsApp Banking is not accessible in the North-Central region. Some of the reason for these findings might be that the banks concerned have not promoted their banking strategy to a reasonable extent or maybe customers are comfortable with other methods of conducting banking activities, for instance, other internet platforms like mobile apps, internet banking or Unstructured Supplementary Service Data (USSD). In terms of the respondents' use of WhatsApp Banking, findings corroborated the users' lack of awareness of the technique. A critical observation of the data reveals the users' responses to the research question. Only 5.18\% asserted that they use the method of banking always, $13.21 \%$ use it sometimes, and 3.36\% rarely use the platform for banking activities. The reasons for these findings may not be unconnected to the reason offered above: reasons why there is poor awareness of WhatsApp Banking.

For the audience's perception and assessment of WhatsApp Banking, the data shows that the audience believes that the banking method will be advantageous and will complement other banking methods. The above findings are in tandem with other studies (Hajli, 2014; Chen and Beaudoin, 2016; Bohlin, Shaikh and Hanafizadeh, 2018) that have found that social media platforms promote businesses and foster interaction between customers and organizations, create and develop new and real ways of connection and have a tremendous prospect for businesses, specifically financial institutions. Scholars have argued that the emergence of social media has made our day to day activities easy and convenient. This is the argument that the current study corroborates. The respondents confirmed that WhatsApp Banking would establish a personal link between the customer and the bank. Yasa and Mucan (2005) have proffered a similar suggestion. According to the authors, banks need to use social media user-friendly and interactive systems to understand customers' unique needs and create more loyal customers.

Furthermore, the study discovered that the current internet infrastructure in the country might not sustain effective WhatsApp Banking. From experience, other internet-enabled banking methods have experienced hitches. For instance, due to poor internet network, a simple transaction that should not take up to three minutes takes a customer close to twenty minutes to conclude. In some cases, say maybe fund transfers, the recipient does not receive the fund, but the sender is debited. This happens most often due to poor internet network. This and other factors might be the reason that prompted the audience to submit that the current internet infrastructure is incapable of sustaining a hitch-free WhatsApp Banking.

Theoretically, the current study corroborated the domestication theory as used in the study. From the findings of the study, it may be safe to say WhatsApp is not fully appropriated for banking activities because of the deficient awareness. In as much as the banks haye 
domesticated WhatsApp for its services, it is incumbent on them to assist the users in appropriating it by engaging in a robust awareness campaign. Overall, the use of domestication theory in the current study raised the thinking of how users of particular media, in this case, WhatsApp have appropriated and converted the app in banking and related financial activities in North-Central Nigeria.

\section{CONCLUSION}

The adoption of Information and Communication Technology (ICT) in various human endeavours has made these endeavours convenient and hassle-free. Precisely, the use of social media has made communication and other activities cheaper and even more convenient. As seen in this study, the adoption of WhatsApp in banking and financial activities is yet another inclusion of social media in an essential sector of our lives especially at a time when major human activities are being conducted online. The major finding of this study which is a contribution to knowledge in WhatsApp studies is that a considerable number of the respondents do not have access and are not aware of WhatsApp Banking; the majority of the respondents do not use the platform for banking and other financial activities.

Stated differently, the research participants believe that a vast awareness campaign might increase the use of the platform. Hence, the indication is that inadequate publicity from the banks could be responsible for this trend. Being a new innovation, the study established that WhatsApp Banking would add a significant advantage to banking and other related activities. Nevertheless, the respondents are sceptical that the country's current internet infrastructure might not create an enabling ground for the innovation to thrive with minimal or no hitches. Hence, the study recommends that banks should endeavour to create more awareness on WhatsApp Banking, and there is a need for an urgent improvement in internet infrastructure and connectivity in the country.

\section{REFERENCES}

Adalarasu, B. \& Padmaavathy, P. (2016). Role of social media in banking. International Journal of Advance Research in Computer Science and Management Studies, 4(5), pp. $230-237$.

Ahad, A.D., \& Lim, S. (2014). Convenience or nuisance? The "WhatsApp" dilemma. The International Conference on Communication and Media. Retrieved from http://www.repo.uum.edu.my

Alotaibi, M. (2013). The impact of twitter on Saudi banking sectors in the presence of social media: an evaluative study. Journal of Library \& Information Science, 3(4), pp. 618630.

Ayotunde, A. (2012). Changing technology and the Nigerian mass media. Kuwait Chapter of Arabian Journal of Business and Management Review, 2(3)

Bullas, J. (2014). 22 Social media facts and statistics you should know in 2014. Retrieved from: http://www.jeffbullas.com/2014/01/17/20-social-media-facts-and-statistics-youshould-know-in-2014/ 
Costin, D. (2015). Banking business and social media-a strategic partnership. Theoretical and Applied Economics, 22 (4), 605.

Dawar, P. (2013). A study of factors affecting customer satisfaction in present highly competitive banking.

Dehghani, M., Nourani, S., \&Abardeh, H.C. (2012). The role of social media advertising in motivating consumer in banking services. Interdisciplinary Journal of Contemporary Research in Business, 4 (8), pp. 774-787

Deirdre, H. (2007). Applying domestication: how the internet found its place in the home. Retrieved from:www.irma-international.org/viewtitle/33188/.

Dinesh, T. C. (2011). New age banking in the digitized and networked world of social.

Hyne, D. \& Richardson, H. (2009). What use is domestication theory to information systems research? Retrieved from: http://biblio.uabcs.mx/html/libros/pdf/11/27.pdf

How Nigerian Banks are innovating with "WhatsApp Banking" (2018). Retrieved from: https://techpoint.africa/2018/09/18/whatsapp-banking-nigeria/

Jisha, K. \&Jebakumar. (2014). WhatsApp: a trend setter in mobile communication among chennai youth. IOSR Journal of Humanities and Social Science.19 (9). 01-06. Retrieved from www.iosrjournals.org.

Khan, F.R., Hatami, Y.J., Sasidharan, A., \&Al-Roshdi, S.A. (2017). Investigative study of preferred social media marketing in Safeer Mall, Sohar, Oman, Humanities and Social Science Reviews, 5(1), pg.53-63.

Kirakosyan, K. (2014a). Social media usage in banking industry and its managerial view: case study for Mexican banking system. "Journal of Economic and Social Development, 2(1), 34-43.

Kirakosyan, K. (2014b). The managerial view of social media usage in banking industry: cast study for Romanian banking system. Proceedings of the 8th International Management Conference, Management Challenges for Sustainable Development, West University of Timisoara, Nov.6th \& 7th, 2014, Bucharest, Romania, pp.225241.

Miranda, F. J., Barriuso, C., \& Cortés, R. (2006). Quantitative evaluation of e-banking web sites: An empirical study of Spanish banks. The Electronic Journal of Information System Evaluation, 73-82.

Mutunga, N.E. (2014). Perceived links between social media strategy and organization performance among mobile telephony companies in Kenya. A Research Project Report Submitted to School of Business, University of Nairobi, pp. 1-58. 
Njoroge, C. and Koloseni, D. (2015). Adoption of social media as full-fledged banking channel: an analysis of retail banking customers in Kenya. International Journal of Information and Communication Technology Research, 5(2), pp. 1-12

Rabb, A. (2015). A study on customer's satisfaction towards banking services of state bank of India in Kanyakumari district," International Journal of Management and Commerce Innovations, 2 (2), pp. 249-443.

Ruppert, L. (2013). Integration of social media with CRM in banking and financial services by Louisa Rupert.

Silverstone, R., Hirsch, E. \& Morley, D. (1992). Information and communication technologies and the moral economy of the household, in R. Silverstone and E.Hirsch (eds.) Consuming Technologies Media and Information in Domestic Spaces. London and New York: Routledge.

Simon, K. (2019, January). Digital report: Nigeria. Retrieved from: https://datareportal.com/reports/digital-2019-nigeria

Udenze, S. (2017). Is whatsapp messaging subsuming conventional SMS? International Journal of Advanced Research and Publications. 2 (3), pp. 20-25.

Udenze, S. (2019a). Print media and the challenges of social media. International Journal of Advanced Research and Publications, 2 (3), pp. 105-109.

Udenze, S. (2019b). WhatsApp platform for collaborative learning among students of University of Abuja. Unpublished MA thesis submitted to the Department of Theatre Arts, University of Abuja, Nigeria.

WhatsApp FAQ- Using WhatsApp group chat (2017).Retrieved from https://www.whatsapp.com/faq/en/general/21073373.

WhatsApp, not Instagram, is the preferable platform for small businesses in Nigeria (September, 2019). Retrieved from: https://techpoint.africa/2019/09/23/whatsapp-notinstagram-is-the-preferable-platform-for-small-businesses-in-nigeria/.

Yamane, T. (1967). Statistics: An introductory analysis (2nd Ed.). New York: Harper and Row.

Yasa, E. \&Mucan, B. (2005). How Turkish banks benefit from social media: analyzing banks formal links. International Journal of Strategic Innovative Marketing, Vol. 1, pp. 120129. DOI: 10.15556/IJSIM.01.02.005.

Zembik, M. (2014). Social media as a source of knowledge for customers and enterprises. OnlineJournal of Applied Knowledge Management, 2(2), pp.132-148. 